\title{
THE EARTHQUAKE OF 426BC IN N. EVOIKOS GULF REVISITED: AMALGAMATION OF TWO DIFFERENT STRONG EARTHQUAKE EVENTS?
}

\author{
Papaioannou I. ${ }^{1}$, Papadopoulos G.A. ${ }^{2}$, and Pavlides S. ${ }^{3}$ \\ ${ }^{1}$ A. Panagouli str. 10, 41222 Larissa, Greece \\ 2 Institute of Geodynamics, National Observatory of Athens, 11810, Athens, Greece \\ g.papad@gein.noa.gr \\ 3 Department of Geology, Aristotle University of Thessaloniki, 54124, Thessaloniki, Greece \\ pavlides@geo.auth.gr
}

\begin{abstract}
An examination of historiographic and seismological studies of the last two centuries showed that probably some of them amalgamated the $426 \mathrm{BC}$ earthquake event of Maliakos Gulf with a second earthquake occurring later in the same area. Reexamination of the classical documentary sources regarding the earthquake of $426 \mathrm{BC}$ and its associated tsunami revealed the different descriptions of Thucydides and Strabo as well as several inconsistencies that characterize their texts. These imply that possibly two different earthquakes occurred in the area of Maliakos Gulf during the $5^{\text {th }}$ and $3^{\text {rd }}$ centuries BC. This hypothesis is further supported by archaeological evidence which indicates that the destruction horizons found in excavations in Lamia and Oreos were caused by strong earthquake activity. The first is dated around middle $3^{\text {rd }}$ century $\mathrm{BC}$, while the second is dated from 225 to $215 \mathrm{BC}$. Regarding the first of the suggested earthquakes, the information that only Peparethus (Skopelos) was damaged indicates that possibly it wasn't so strong. Chronologically this event should be placed on the summer of 426B.C. On the contrary, it seems that the second event was very strong, given that it affected many places in a large area of destruction. This earthquake probably occurred after 426B.C. and its terminus post quem is around 200B.C. The archaeological destruction may represent the earthquake described by Strabo that is the second event.
\end{abstract}

\section{INTRODUCTION}

The earthquake and its associated tsunami that reportedly occurred in Maliakos Gulf, Central Greece, on 426B.C. is one of the most frequently seismic events considered to have taken place in antiquity (see reviews in Antonopoulos, 1992 and Guidoboni et.,1994). The classical documentary sources are those of Thucydides, Strabo and Diodoros. Strabo was based on the lost catalogue of ancient earthquakes compiled by Demetrius of Callatis ( 200B.C.), while it seems that Diodoros just merged information taken from both Thucydides and Demetrius. The text of Thucydides clearly implies that the earthquake occurred on the summer of 426B.C. However, in his text Strabo does not indicate that he refers to the particular earthquake reported by Thucydides. In addition, in some historiographic studies it has been suggested that Strabo possibly reported on an earthquake event that occurred during the $3^{\text {rd }}$ century BC.

In this paper we reevaluate both the classical documentary sources and modern historiographic, seismological and archaeological studies and conclude that possibly two different earthquake events were amalgamated to one. 


\section{PREVIOUS STUDIES}

In modern times, the studies that examined the particular earthquake event(s) can be grouped in four groups. The first includes 19th century earthquake catalogues that ignored Strabo, were based only on Thucydides and Diodoros and referred to the summer 426BC shock. Historiographic studies of the second group, like those of Neumann and Partsch (1885) and Capelle (1908), made an undiscriminate use of the information given by some previous authors, who copied Thucydides and Strabo, and supported that a single earthquake took place around the Maliakos Gulf during the summer of $426 \mathrm{~B}$.C. In the third group, that is in 20th century seismological studies, this idea was uncritically reproduced in historical catalogues compiled by Sieberg (1932) and others. Moreover, in some of them, like Sieberg (1932), - Bousquet et Pechaux (1978) and Papazachos et al. (1997), isoseismal maps of that "single" earthquake event were constructed. However, some early 20th century historiographic studies, that is the fourth group of studies, reported on Strabo and described a different earthquake occurring on the 3rd century BC (Vortselas,1907, Beloch 1911, 1924, Schober, 1924, Bequignon,1937). It is apparent that the 20th century seismological studies ignored the fourth group of studies and amalgamating Thucydides, Strabo and Diodoros referred to only the summer 426BC earthquake.

Because of the confusion prevailing in modern literature we proceded to a reexamination of the documentary sources of Thucydides, Strabo and Diodoros in an effort to clarify what they have in common and what are the points of deviation.

\section{DOCUMENTARY SOURCES}

\subsection{Thucydides}

The text of Thucydides reports about a strong sea -wave that attacked Orovies in NW Evia, Atalante in Lokris and Peparethus (Skopelos Isl.) in the west part of the north Aegean Sea (Figure 1). The only mention about earthquakes is that Peparethus suffered some damage.
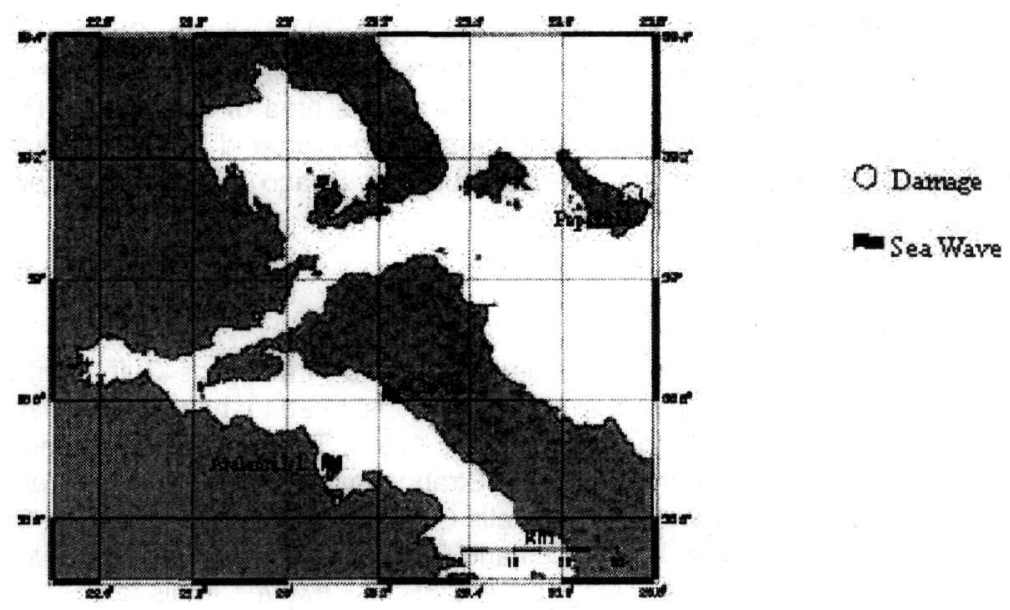

Figure 1. The macroseismic field according to Thucydides. 


\subsection{Strabo}

On the contrary, the text of Strabo is much more detailed and presents a different macroseismic field (Figure 2). In particular, extensive destruction with building collapses is reported in both sides of the Maliakos Gulf and in Lokris, ground failures are described in Maliakos Gulf and north Evia, a sea - wave (or tsunami) attack is described in Skarfia, Thronio, Thermopyles and Dafnous, while it is also reported that a fault was generated in Atalante. The earthquake effects described by Strabo are analyzed below. Locations can be found in Figure 2.

\subsubsection{Effects on buildings}

Heavy damage was observed in Echinos, Falara, Heraclea, Thronio, Skarfia, Lamia and Larissa. A lot of damage is reported from Alopi, Cynos, Opus and Oion, while it seems that Elatia was less damaged. In Alponon a tower close to the harbour collapsed.

\subsubsection{Ground failures}

It is reported that Lichades and Cynaeum submerged. The rivers Sperchios and Voagrios changed their courses, while in Aedipsos and Thermopylae changes were observed in thermal springs. In Atalante, a ground fissure was observed, while at the same time a land strip that used to form a peninsula off the Greek mainland was torn through to form an islet.

\subsubsection{Tsunami}

A strong tsunami was observed in Skarfia, Thronio, Thermopyles and Dafnous. Sea-wave was also reported from Atalante.

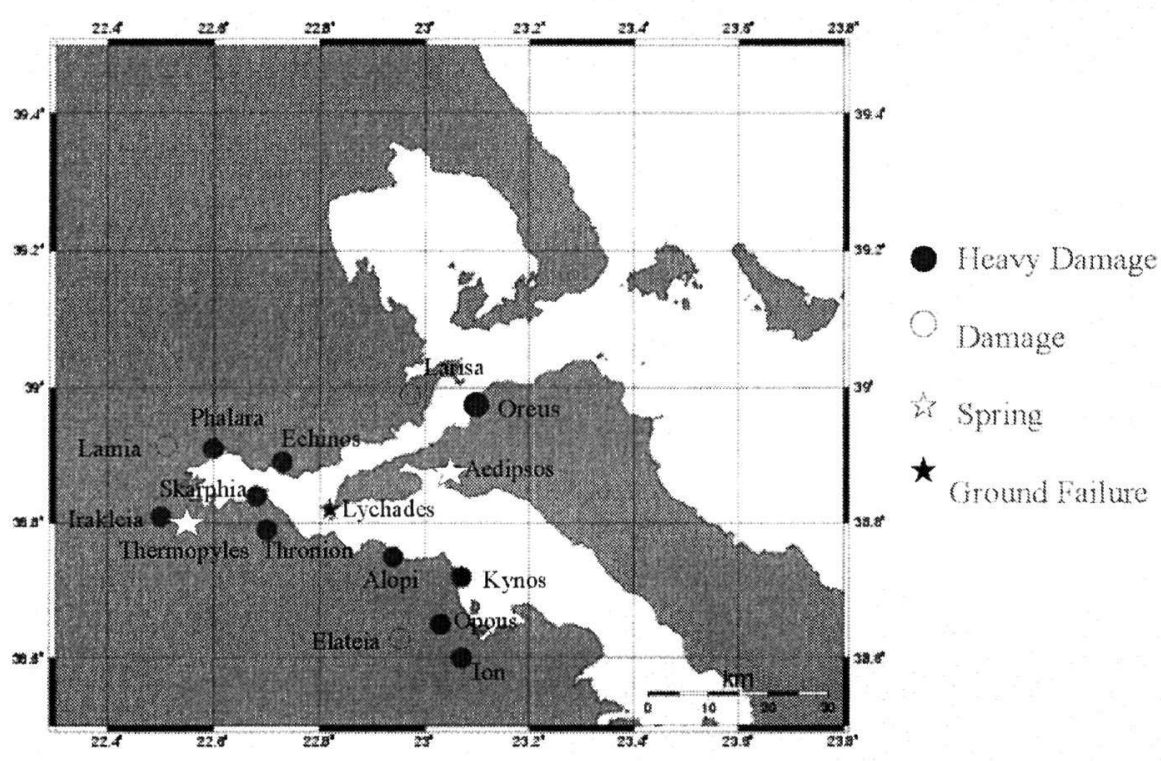

Figure 2. The macroseismic field according to Strabo.

\subsection{Diodoros}

The text of Diodoros practically does not yield additional information, some importance being related only with the description that the isthmus of a peninsula in Locris was fractured and the island called Atalante was generated, which seems to fit Strabo's description.

A comparison of the texts of Thucydides and Strabo indicate that no common localities of earthquake and tsunami effects can be found. The only exception is Atalante. In addition, the De-

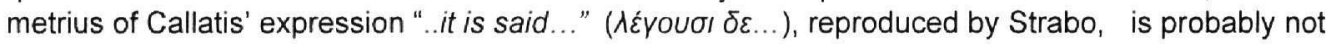


referred to the event described in the rest part of the text. Only little doubt remains that if the earthquake effects described by Strabo had occurred on the summer of 426B.C. they would not escape the attention of a careful and reliable historian like Thucydides.

\section{A HYPOTHESIS FOR TWO DIFFERENT EARTHQUAKE EVENTS}

Because of the different descriptions made by Thucydides and Strabo we have made the hypothesis that these two writers possibly described two different earthquake events. This hypothesis is reinforced by some obvious inconsistencies noticed by comparing the two texts. In fact, Strabo reported that the town of Heraclea was destructed by the shock, whereas according to Thucydides this town was built after the occurrence of the 426BC earthquake. Therefore, the destruction of Heraclea should be attributed to a latter earthquake. Moreover, according to Thucydides the season of summer was ranging from March to October, which deviates from Strabo's description that because of the earthquake one of the harbour towers collapsed killing twenty-five girls who were gathered to attend the Thesmophoria celebration. The inconsistency concerns that the Thesmophoria celebration was taking place by the end of October to the beginning of November, which means that only marginally fits the summer season reported by Thucydides for the 426BC earthquake. As a consequence, we favour the explanation that the Thucydides' event, that of summer 426BC, is different from that of Demetrius Callatis and Strabo which should have taken place after 426BC. Demetrius of Callatis lived around $200 \mathrm{BC}$ and, therefore, this is roughly a terminus post quem of the earthquake. This implies that the suggested second event took place possibly during the 3rd century BC.

\section{ARCHAEOLOGICAL EVIDENCE}

Archaeological evidence about an earthquake destruction in the area of Maliakos Gulf around the 3rd century BC supports further our hypothesis. According to Dakoronia (2000, also personal communication) an archaeological excavation in the city of Lamia revealed the collapse of the external part of the ancient city wall, which the archaeologists attributed to a strong earthquake dated between the end of $4^{\text {th }}$ century and the beginning of 2 nd century BC. An independent, second archaeological evidence comes from the excavation in Oreos where the destruction of the roof of a house was observed and attributed by the archaeologists to a strong earthquake (Ritsonis, 2004, personal communication). The event seems that have taken place by the end of 3rd century BC, possibly between 225 and 215 B.C. This date range has been indicated from coins, gutter of roof and potsherds found in the house with the collapsed roof (Ritsonis, 2004, personal communication).

\section{CONCLUSIONS}

On the basis of the different descriptions of Thucydides and Strabo and several inconsistencies that characterize the two texts, we suggested that possibly two different tsunamigenic earthquakes occurred in the area of Maliakos Gulf during the $5^{\text {th }}$ and $3^{\text {rd }}$ centuries BC. This hypothesis is further supported by archaeological evidence which indicates that the destruction horizon found in excavations in Lamia and Oreos was caused by strong earthquake activity during the $3^{\text {rd }}$ century BC. Should this interpretation is correct, then one may also revise the tsunami information contained in tsunami catalogues. In the most recent one, Papadopoulos (2001) lists the 426BC event assigning to intensity 4 . The new interpretation shifts this estimation to the suggested event of $3^{\text {rd }}$ century $B C$, while the $426 B C$ wave may assigned a smaller intensity.

Regarding the first of the suggested earthquakes, the information that only Peparethus (Skopelos) was damaged indicates that possibly it wasn't so strong. Chronologically this event should be placed on the summer of 426BC. On the contrary, it seems that the second event was very strong, given that it affected many places in a large area of destruction. This earthquake probably occurred after 426B.C. and its terminus post quem is around 200BC. Archaeological excavations revealed seismic destruction horizons in Lamia and Oreos. The first is dated around the middle of the $3^{\text {rd }}$ 
century $\mathrm{BC}$ while the second is dated from 225 to $215 \mathrm{BC}$. These destruction horizons may represent the earthquake event described by Strabo.

It would be of interest to determine the epicenters and magnitudes of these earthquakes. However, the available data are not adequate enough to make an effort towards this purpose.

\section{REFERENCES}

\section{Classical sources}

Diodoros. Liber XII, 58.

Strabo. Geographika I, 3.20

Thucydides. Historiae III, 89.2 and 89.5

\section{Contemporary sources}

Antonopoulos, J., 1992. The tsunami of 426BC in the Maliakos Gulf, Eastern Greece, Natural Hazards, 5, 8393.

Beloch, K.J., 1911. Klio, XI, Leipzig, Theodor Weicher, 441.

Beloch, K.J., 1924. Griechische Geschihte I, Berlin und Leipzig, Walter de Gruyter \& Co, 55.

Béquignon, Y., 1937. La vallée du Spercheios des origins au $N^{E}$ sieclé, études d'archéologie et de topographie, Paris, E. de Boccard, 69-73.

Bousquet, B. And Pechoux, P.Y., 1978. Recherches bibliographic sur la seismicite historique. Rapport Final D' Avtivite Scientifique de l' Equipe du Laboratoire de Geologie Dynamique de l' Universite Paris Sud sur le resultat des etudes de Neotectonique en Greece, 3, 47-65, 4, 93-126.

Capelle, W., 1908. Erdbebenforschung, Paulys Realencycl. Class. Altert., suppl 2, 603.

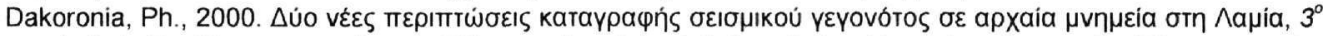

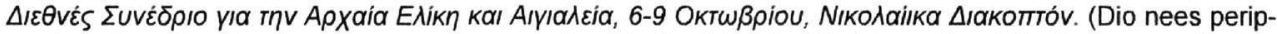
toseis katagrafis seismikou gegonotos se archaia mnimia sti Lamia, 3th International Conference on Ancient Helike and Aigialeia, 6-9 October, Nikolaiika of Diakopton. )

Guidoboni, E., Comastri, A. and Traina, G., 1994. Catalogue of ancient earthquakes in the Mediterranean area up to the 10th century. SGA Storia Geofisica Ambiente, Bologna, 504pp.

Neuman, C. und Partsch, J., 1885. Physikalische Geographie von Griechenland, Breslau, Verlag, 321-322.

Papadopoulos, G.A., 2001. Tsunamis in the East Mediterranean: A catalogue for the area of Greece and adjacent seas. Proc. 1OC-IUGG Internatl. Workshop Tsunami Risk assessment Beyond 2000:Theory, Practice and Plans, June 14-16, Moscow, 2000, 34-43.

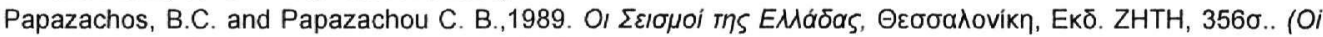
seismoi tis Ellados, Thessaloniki, Ziti Edit., 356pp.)

Papazachos, B.C. and Papazachou C. B.,1997. The earthquakes of Greece, Thessaloniki, Ziti Edit.,304 pp.

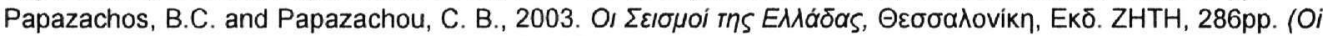
seismoi tis Ellados, Thessaloniki, Ziti Edit., 286pp.)

Papazachos, B.C., Papaioannou, Ch., Papazachos, C.B. and Savvaidis, A.A., 1997. Atlas of isoseismals maps for strong earthquakes in Greece and surrounding area. Publ. Geoph. Lab. Univ. Thessaloniki, 4, 200pp.

Schober, F., 1924. Phokis. Inaugural-Dissertation, Jena.

Sieberg, A. Erbebengeographie, Handbush der Geophysik, Berlin, 4.

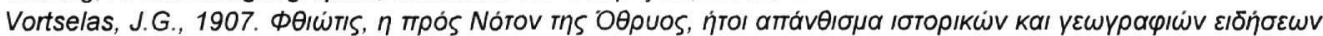

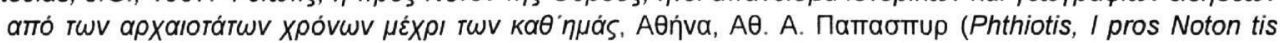
Orthrios, iti apanthisma istorikon kai geographikon idiseon apo ton archaiotaton chronon mechri ton kath' imas, Athens, A.A. Papaspy) 